\title{
Mäns yrkesliv från medelålder till pensionering
}

Tobias Karlsson

Individens livscykel har historiskt sett olika ut för män och kvinnor, inte minst när det gäller livets senare skeden. I det här kapitlet studeras mäns yrkesliv från medelålder till pensionering med utgångspunkt i en enskild berättelse. Denna berättelse jämförs med de typiska mönster för yrkesaktivitet och inkomstutveckling som framträder i Göteborgs befolkningspanel för män i samma generation.

\section{Bakgrund}

Det finns i alla samhällen uppfattningar om vad som markerar ålderdomens inträde, och uppfattningarna skiljer sig åt över tid och rum. ${ }^{1}$ I vårt moderna samhälle är pensioneringen - utträdet från arbetskraften - den kanske tydligaste markören för inträdet i ålderdomen. Pensionen förväntas innebära en försörjning på en så pass hög nivå att förvärvsarbete inte längre är nödvändigt. ${ }^{2}$ Vi kan inte utgå från att pensionering hade samma innebörd för 100 år sedan. Visserligen blev Sverige 1913 det första landet i världen som införde ett allmänt pensionssystem, det vill säga ett system som inte ställde krav på tidigare förvärvsarbete för rätt till pension och där pensionens storlek inte berodde på tidigare förvärvsinkomster. Inledningsvis var folkpensionen dock låg - dess storlek möjliggjorde inte ett fullständigt utträde från arbetsmarknaden, den skulle snarast ses som ett komplement till andra inkomstkällor. Pensionären måste fortsätta att 
arbeta, ta av sina besparingar eller utnyttja fattighjälp för att klara försörjningen. ${ }^{3}$

I och med pensionsreformen fick alla, oavsett tidigare anställningsförhållanden, rätt att ansöka om ålderspension vid 67 års ålder. Men det fanns diskussioner om att ha olika pensionsåldrar för män och kvinnor. Detta faktum påminner oss om vikten av att vara uppmärksamma på skillnader mellan könen när det gäller äldres arbete och försörjning. Män var nästan alltid yrkesaktiva i medelåldern, och grundläggande frågor är när och under vilka förutsättningar de slutligen lämnade det yrkesaktiva livet. Kvinnor, å sin sida, närmade sig ofta ålderdomen från positioner utanför den formella arbetsmarknaden. Det blir då minst lika intressant att fråga sig i vilken omfattning de sökte sig in på arbetsmarknaden på äldre dagar eller om de skaffade sig andra typer av försörjningskällor. ${ }^{4}$

I det här kapitlet fokuserar jag dock på de medelålders och äldre männens erfarenheter. Jag vill belysa övergången från vuxenliv till ålderdom för män, med fokus på hur deras arbete och försörjning gestaltade sig fram till utträdet från arbetsmarknaden. Hur avslutades den yrkesaktiva delen av deras liv? Var det en livsfas som kännetecknades av stabilitet och trygghet, där de äldre männen kunde förbereda sig för att så småningom lämna arbetsmarknaden? Eller var det snarare en fas som präglades av stora förändringar och negativa överraskningar, där de äldre männen trängdes undan - av nya generationer och nya teknologier?

Efter en kortfattad genomgång av tidigare forskning på området använder jag ett individuellt livsöde - varvssmeden Oskar Hammarström - som utgångspunkt för en kvantitativt inriktad undersökning av äldre mäns erfarenheter på arbetsmarknaden i Göteborg. Hammarströms berättelse ger intrycket av att han upplevde den senare delen av sitt yrkesverksamma liv som tämligen oproblematisk. Hans livsresa började med utmaningar och svårigheter och avslutades med en angenäm tillvaro.

Frågan är emellertid om Oskar Hammarströms erfarenhet var typisk för män $\mathrm{i}$ hans generation. För att närma mig denna fråga har jag följt en kohort av män som bodde i Göteborg 1915 och som var 
födda ungefär samtidigt som Oskar Hammarström. Jag tittar exempelvis närmare på inkomstutveckling över tid, eventuell arbetslöshet och utträdet från arbetskraften. Jag studerar också yrkesrörligheten bland medelålders män för att ta reda på om det fanns särskilda reträttpositioner för äldre män.

\section{Optimister och pessimister i den tidigare forskningen}

I den historiska forskningen finns olika uppfattningar om hur, och varför, äldres situation på arbetsmarknaden har förändrats över tid. Grovt sett kan forskarna på detta fält delas upp i optimister och pessimister. Optimisterna menar att de stigande realinkomster som följde med industrialiseringen gjorde det möjligt för äldre män att spara och planera för sin ålderdom. När det gäller svenska förhållanden kan vi konstatera att realinkomsterna steg kraftigt under slutet av 1800- och början av 1900-talet samtidigt som utbudet av sparformer blev mer varierat. ${ }^{5}$ Mellan 1880 och 1913 fördubblades reallönerna och en allt mindre andel av hushållsbudgeten behövde läggas på livsmedel. ${ }^{6}$ Sparbanksrörelsen hade etablerats under 1800-talet, och år 1900 fanns ungefär ett sparkonto per invånare. I slutet av 180o-talet slog sjukkasserörelsen igenom, samtidigt som affärsbanker började erbjuda sina tjänster till vanliga medborgare.? Under 1900-talets första decennier slog också liv- och kapitalförsäkringar, så kallade folkförsäkringar, igenom på allvar, först bland tjänstemän och högkvalificerade arbetare, sedan i bredare grupper. ${ }^{8}$ Dan Bäcklund och Kristina Lilja menar att "sparandet ökade i takt med att överskotten blev större och sparmotiven breddades till att omfatta även ett planerat långsiktssparande”, redan före folkpensionen $1913 .{ }^{9}$ Inledningsvis var det främst yngre och medelålders män som skaffade sig liv- och kapitalförsäkringar. Denna nya sparform var delvis stängd för de äldre, som därför i högre utsträckning var hänvisade till banksparande.

Pessimisterna menar att industrialiseringen, moderniseringen och rationaliseringen medförde en omfattande utslagning av äldre arbetskraft. Denna uppfattning hade även många samtida iakttagare. I 
Tyskland menade Verein für Sozialpolitik (Föreningen för socialpolitik) att det särskilt vid större företag i början av 1900-talet skedde en utgallring av mindre produktiva arbetare som bland annat baserades på ålder. ${ }^{10}$ På 1920-talet skrev den amerikanske ekonomen Abraham Epstein att "i maskinernas värld är ålder och erfarenhet inte längre några tillgångar utan oöverstigliga handikapp" ${ }^{11}$ Mellankrigstidens rationaliseringsrörelse yttrade sig bland annat i ökad användning av ackordslöner, tidsstudier och en tydligare arbetsdelning mellan arbetare och tjänstemän. ${ }^{12}$ Åke Elmér, som skrivit om bakgrunden till den svenska folkpensionen, menar att rationaliseringarna kan ha missgynnat äldre och påskyndat deras utträde från arbetsmarknaden. ${ }^{13}$

De få svenska studier som gjorts om hur äldre mäns situation på arbetsmarknaden gestaltade sig under 1900-talets första decennier ger en blandad bild. Ann-Kristin Högman har observerat sjunkande yrkesaktivitet bland män över 60 år i svenska städer mellan folkräkningsåren 1910 och 1930, samt att män i denna åldersgrupp var underrepresenterade i växande industrier och moderna yrken. ${ }^{14}$ Dessa mönster kan åberopas som stöd för en mer pessimistisk tolkning av äldre mäns situation på arbetsmarknaden. Även Birgitta Skarin Frykman, som undersökt bageriarbetare i Göteborg, kan räknas till pessimisterna. Hon fann att det i slutet av 1800-talet fanns mycket få äldre bagare, trots att det inte var ett tillfällighetsjobb. Enligt en samtida iakttagare var "åsikten allmän bland mästarna, att den som var över fyrtio år var för gammal”. ${ }^{15}$ Lars Olsson, som undersökt typografer, en annan yrkesgrupp med få äldre utövare, riktar fokus mot hur arbetsprocesserna förändrades under 1900-talet och ger en mer optimistisk bild av åldrandet. Med undantag för åren efter storstrejken 1909 samt under depressionen i början av 1930-talet fann han inga starka belägg för att det skulle ha förekommit någon utgallring av äldre typografer. ${ }^{16}$ Men som Olsson själv påpekar handlade det om en manligt dominerad yrkeskår som hade en hög facklig organisationsgrad och därmed en stark förhandlingsposition i förhållande till arbetsgivarna. ${ }^{17}$ 


\section{En varvssmeds berättelse}

Det finns många tänkbara källor för att studera äldre mäns situation på arbetsmarknaden historiskt sett. En tänkbar källa, för den som intresserar sig för personer som var medelålders när folkpensioneringen infördes 1913 och som lämnade arbetskraften under mellankrigstiden, är Nordiska museets så kallade arbetarminnen. De samlades in på 1940- och 1950-talen under ledning av etnologen Mats Rehnberg och i samarbete med bland annat fackliga organisationer. Nordiska museet vände sig till ett antal viktigare arbetargrupper, däribland de i Göteborg så framträdande verkstadsarbetarna.

Informanterna var ofta äldre personer, födda på 1850-, 1860- och 1870-talen. De hade kommit in på arbetsmarknaden under den tidiga industrialiseringen, då arbetslivet fortfarande präglades av husbondevälde och mycket enkel teknologi. Som vuxna fick de uppleva hur arbetslivet moderniserades i många avseenden. Arbetarna organiserade sig fackligt. Maskinerna blev fler och snabbare och arbetslokalerna ljusare. Ett problem för vårt vidkommande är emellertid att de minnen som samlades in domineras av upplevelser från barndom och uppväxt. ${ }^{18}$ Skildringar av hur arbetslivet gestaltade sig när ålderdomen närmade sig är mer sällsynta. Den i Göteborg verksamme varvssmeden Oskar Hammarströms berättelse är ett tydligt exempel.

Oskar föddes 1869 i Harestad, 1,5 mil fågelvägen från Göteborg. ${ }^{19}$ Fadern var indelt soldat och Oskar fick tidigt hjälpa modern i familjens jordbruk. Efter konfirmationen, vid omkring 15 års ålder, fick han arbete hos en smedmästare i Göteborg. Under de följande 10-15 åren flyttade han ett par gånger mellan uppväxtorten och storstaden och bytte arbetsgivare flera gånger. Efter att under något år ha försökt driva en egen smedja i hembyn återkom Oskar till Göteborg som smedshantlangare, och senare verktygssmed, vid Keillers (som senare blev Götaverken). ${ }^{20}$ Han var med om företagets flytt till Hisingen och den modernisering av arbetet som den medförde.

För att få upp lönen tog Hammarström som 40-åring tjänst vid Strömman \& Larssons snickerifabrik, ett mindre men växande företag alldeles i närheten av Götaverken. Han sade sig ha ångrat bytet 


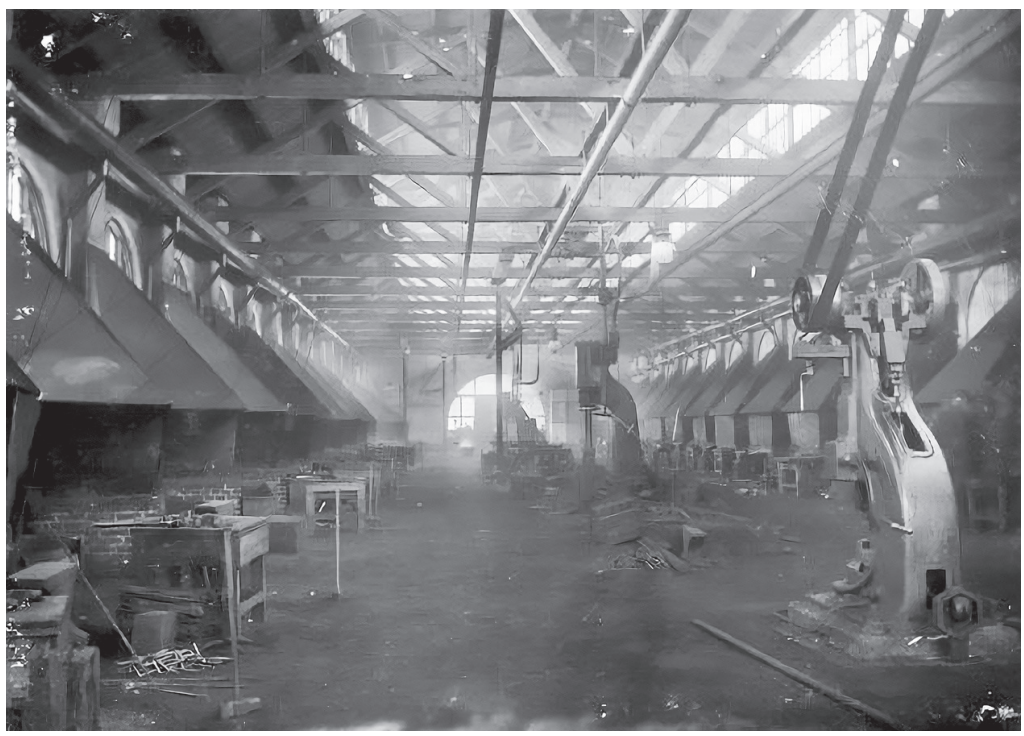

Bild 9.1. Varvssmedjan vid Götaverken år 1901, som då var belägen Inom Vallgraven på Stora Badhusgatan 3. Foto: Carl Mikael Olson, Göteborgs stadsmuseum.

eftersom förhållandena på den nya arbetsplatsen framstod som ålderdomliga och utsikterna till fortsatt löneutveckling som obefintliga, men han stannade kvar i nästan ett decennium.

När Oskar närmade sig de 50 vände han åter till Götaverken och fick då en dramatisk lönehöjning: från 40 till 70 kronor per vecka. "Efter denna tid är inget att anteckna", fortsätter Oskar sin berättelse. ${ }^{21}$ "Åren gingo och tiden för att bliva pensionerad var överskriden, för jag slutade mitt arbete den 16 juli 1941, samma dag jag fyllde 72 år."22

På två meningar avhandlas alltså de två årtionden som följde efter återkomsten till Götaverken. Inget om arbetstempo och rationaliseringar, eller om arbetslöshet och ekonomiska kriser, eller om hur arbetskamraterna eller ledningen förhöll sig till en åldrande varvssmed. Inget om varför Oskar stannade kvar flera år efter att han uppnått den formella pensionsåldern eller om hur han upplevde det slutliga avskedet.

Skildringen av ungdomstiden och de tidiga vuxenåren är inte bara rikare utan innehåller också mer av förändringar, problem och 
svårigheter. Barndomshemmet var fattigt, det enda rummets tak buktade nedåt som en "hängmatta" och i avsaknad av ved eldade familjen med kospillning. ${ }^{23}$ Från skoltiden minns Oskar aga och auktioner av föräldralösa barn och hemlösa åldringar. Som lärpojke hos smedsmästare Kallbäck i Göteborg fick han vattenblåsor i händerna och stå ut med såväl gesällernas pennalism som en äldre smeds häftiga humör. ${ }^{24}$

När Oskar i 20-årsåldern återkom till Kallbäcks smedja efter att ha fullgjort det första årets värnpliktstjänstgöring möttes han av beskedet att platsen "var upptagen av en yngre förmåga". ${ }^{25}$ Från sin nästa anställning, vid Eriksbergs mekaniska verkstad, blev Oskar avskedad efter en kort tid på grund av att han och några kamrater tagit en fridag. Därefter förlorade han en anställning vid Lindholmens mekaniska verkstad till följd av företagets konkurs 1892.

I 25-årsåldern drabbades Oskar av "tryckvärk" i en hand. Han remitterades till Sahlgrenska sjukhuset för operation men struntade i det. Istället skar han upp den böld som uppstått på handen med sin rakkniv, smorde på en salva från en klok gumma ("Kungsbackagumman”) och var kort därefter tillbaka i arbete. Några ålderskrämpor finner inte Hammarström värda att nämna i sin berättelse. Vi kan förmoda att han överlag hade en relativt god hälsa. I inledningen av sin berättelse konstaterade den 81-årige Oskar att han, i likhet med sin far, "aldrig heller behövt ligga för sjukdom". ${ }^{26}$ Det bör vi ha i åtanke när vi reflekterar över hans livsberättelse. Hade Oskars levnadsbana kantats av olycksfall och sjukdomar hade den sannolikt haft större inslag av otrygghet, exempelvis med avseende på yrke och inkomster.

Oskars berättelse om barndomen, ungdomen och det tidiga vuxenlivet är innehållsrik och full av förändringar. Efter hans återkomst till Götaverken följer en lång period av förmodad stabilitet. Tonvikten på erfarenheter i livets tidigare skeden är delvis en följd av de instruktioner som Nordiska museet gav sina informanter. Just i Oskars fall är det emellertid sannolikt att slutet av hans yrkesverksamma liv faktiskt präglades av kontinuitet. Om han hade bytt arbetsplats, fått helt nya arbetsuppgifter eller blivit ofrivilligt avskedad hade han troligen nämnt det. En grundläggande fråga som infinner sig är hur 
representativ Oskars erfarenheter är: för verkstadsarbetare, för industriarbetare och för medelålders och äldre män i stort under den tid som den senare delen av hans levnadsbana som yrkesaktiv omfattar, det vill säga perioden från 1910-talet till 1940-talet.

Vi bör vara försiktiga med att dra slutsatser av den typ av källmaterial som Nordiska museets arbetarminnen utgör. Minnesinsamlingarnas utformning innebar att personer vars yrkesliv präglades av viss kontinuitet är överrepresenterade. Och även mellan personer som varit verksamma inom samma yrke under hela livet kan erfarenheterna ha skilt sig mycket åt, inte minst beroende på vilket företag de jobbade för. Forskningen om varven i Göteborg har exempelvis visat på stora skillnader i företagens relationer till arbetskraften. Enligt denna forskning tillbringade Oskar de sista årtiondena av sitt yrkesverksamma liv i ett framgångsrikt företag med förhållandevis human personalpolitik.

Redan på 1910-talet hade Götaverken, under Hugo Hammars ledning, passerat Lindholmen som landets största varv. Expansionen fortsatte under 1920- och 1930-talen. Under perioden 1914 till 1944 trefaldigades antalet anställda vid Götaverken. ${ }^{27}$ Parallellt med tillväxten genomfördes stora förändringar i företagets produktion och arbetets organisation. Götaverken gick från att ägna sig åt mångsyssleri och reparationer till att bli mer specialiserat på nyproduktion av allt större fartyg. Arbetets organisation präglades av elektrifiering, mekanisering och rationalisering. Samtidigt tryckte arbetarnas representanter på för att fler arbetsuppgifter skulle avlönas med ackord. Ackordsarbete gav yrkesskickliga arbetare återkommande möjligheter att omförhandla och höja sina löner. ${ }^{28}$ Ackordsarbete innebar också att de yrkesskickliga arbetarna kunde höja sina inkomster genom att eliminera spilltider som annars inte skulle ha utnyttjats produktivt.

Under första världskriget steg livsmedelspriserna i regel snabbare än lönerna. På Götaverken kunde de stigande arbetsförtjänsterna emellertid följa prisutvecklingen. När inflationen efter kriget upphörde fortsatte förtjänsterna att öka bland företagets arbetare. ${ }^{29}$ Det var precis i det läget Oskar återkom till Götaverken och fick sitt stora lönelyft. Efter kriget initierade företagsledningen en reformering av 
lönesystemet vid Götaverken - fler arbeten ackordsattes och lagackord ersattes av individuellt prestationsbaserade löner. Denna individualisering och rationalisering skulle potentiellt ha kunnat missgynna medelålders och äldre arbetare, men Oskars berättelse innehåller inte något som tyder på det. Snarare ger den en positiv bild av arbetslivets omvandling. Det är möjligt att Götaverken inte är representativt och att den medelålders och äldre arbetskraften behandlades annorlunda av andra arbetsgivare.

Vid Lindholmen, det andra stora varvet i Göteborg, var klimatet mellan arbetsgivaren och arbetarna spänt. Direktören Johan Sjöholm, som även var ordförande för Verkstadsföreningen i Västsverige, utgick från att arbetarna höll nere arbetstakten. För att höja tempot infördes striktare övervakning och närvarokontroller i kombination med sänkta ackordspriser. Även vid det tredje stora varvet, Eriksberg, genomfördes systematiska sänkningar av ackordspriserna med syftet att motverka maskning. ${ }^{30}$ Historikern Thommy Svensson använde formuleringen "piskans politik" för att karaktärisera Eriksbergs förhållande till arbetarna under mellankrigstiden. Han diskuterar inte närmare behandlingen av den äldre arbetskraften, men det är inte orimligt att anta att äldre drabbades särskilt hårt när piskan ven.

Inom en och samma bransch kan det alltså ha funnits betydande skillnader i hur äldre män upplevde slutet av sina yrkesverksamma liv under mellankrigstiden. Det behöver knappast påpekas att skillnaderna också kan ha varit stora mellan branscher och yrkesgrupper. En principiell skiljelinje gick mellan arbetare och tjänstemän. Tjänstemännen omfattades i många fall av särskilda pensionsförmåner, men eftersom deras arbetsuppgifter inte var lika fysiskt krävande förväntades de ofta gå i pension senare än arbetare. ${ }^{31}$

Inom arbetarkollektivet tillhörde varvssmederna - grovsmeder och verktygssmeder - den högkvalificerade arbetskraft som varven inte hur som helst kunde göra sig av med i lågkonjunkturer. ${ }^{32}$ Grovsmederna var involverade i den direkta produktionen och tillverkade utrustningsdetaljer, medan verktygssmederna reparerade verktyg och maskiner. Sannolikt var grovsmederna den grupp på varven som påverkades mest av teknologiska förändringar och andra ra- 
tionaliseringar, exempelvis införandet av svetsning av fartygsskrov på 1930-talet.

I de följande avsnitten ska jag närmare granska hur representativ Oskar Hammarström kan ha varit för sin generations smeder och arbetare, först med hjälp av Kommerskollegiums arbetsstatistiska undersökning av större mekaniska verkstäder år 1899 och därefter utifrån databasen GOPP, där individers livslopp kan följas under perioden 1915 till 1943 .

\section{Göteborgs varvssmeder år 1899}

Personer som, likt Oskar Hammarström, var födda omkring 1870 och arbetade vid större mekaniska verkstäder blev år 1899 föremål för en omfattande statistisk kartläggning. Under ledning av Henning Elmquist besökte Kommerskollegiums medarbetare företagen i den aktuella branschen och intervjuade alla arbetare de påträffade enligt ett bestämt enkätformulär. Frågorna handlade om familjeoch boendesituation, social bakgrund, utbildning, yrkesspecialitet, erfarenhet, anställningstid, arbetstid, lön, medlemskap i föreningar och understödskassor, sjukdomar och kroniska lyten samt eventuella erfarenheter av arbetskonflikter. Undersökningen ger en god bild av hur den typiske verkstadsarbetaren såg ut omkring sekelskiftet 1900.

I ett par avseenden sticker Oskar ut från den genomsnittlige verkstadssmeden. För det första tillhörde han inte en smedssläkt. För det andra var han relativt ny i verkstadsindustrin och på arbetsplatsen. Han tillhörde också den minoritet av smederna i åldersgruppen som var fackligt organiserad. Däremot uppgav han sig inte ha några erfarenheter av arbetskonflikter.

I flera avseenden var dock Oskar en typisk representant för sitt yrke och sin generation. Hans veckoinkomst låg något över genomsnittet för staden och väldigt nära genomsnittet för Keillers verkstäder. Liksom över hälften av smederna i åldersgruppen var Oskar gift - han hade gift sig tidigare samma år - och liksom knappt hälften hade han hemmavarande barn. Det var han som försörjde familjen, hans hustru hade ingen sysselsättning utanför hemmet. Liksom de 
Tabell 9.1. Jämförelse mellan Oskar Hammarström och andra smeder i åldern 25-34 år i Göteborgs verkstadsindustri samt vid Keillers verkstäder, år 1899. Källa: Riksarkivet, Kommerskollegium.

\begin{tabular}{lccc} 
& Göteborg & Keillers & Oskar Hammarström \\
\hline Gift (\%) & 56 & 52 & ja \\
Barn hemma (\%) & 47 & 44 & ja \\
Fadern jordbrukare (\%) & 24 & 23 & nej \\
Tid i yrket (år) & 8 & 7 & 2 \\
Anställningstid (år) & 4 & 4 & 2 \\
Veckoinkomst (kr) & 14,86 & 15,37 & 15,50 \\
Medlem i understödskassa (\%) & 94 & 99 & ja \\
Medlem i fackförening (\%) & 31 & 36 & ja \\
Medlem i nykterhetsförening (\%) & 11 & 13 & nej \\
Antal individer & 254 & 124 & 1 \\
\hline
\end{tabular}

allra flesta av sina kollegor var Oskar medlem i en understödskassa, vid Keillers var medlemskapet rent av obligatoriskt. Och liksom de allra flesta av sina kollegor uppgav sig Oskar inte tillhöra någon nykterhetsförening.

\section{Varvssmedens ålderskohort över tid}

År 1899 framstod Oskar Hammarström som en typisk verkstadsarbetare. Han hade vid fyllda 30 år etablerat sig i sitt yrke, nyligen gift sig och fått barn. I detta avsnitt ska jag försöka säga något om hur allmängiltigt Oskar Hammarström livsförlopp framstår för jämnåriga män i Göteborg vid tiden. Jag har använt mig av Göteborgs befolkningspanel (GOPP) och konstruerat en kohort bestående av män som var födda mellan 1865 och 1874, det vill säga inom fem år före och efter Oskar Hammarström. ${ }^{33}$ Jag kallar urvalet "äldrekohorten".

År 1915 bestod kohorten av 158 män, varav 154 var yrkesaktiva. Den sociala strukturen i gruppen framgår av tabell 9.2. I toppen finns en telegrafchef och ett antal högre akademiker, såsom lärare och jurister. I botten finns ett drygt 30-tal okvalificerade arbetare, exempelvis månadskarlar, tillfällighetsarbetare eller kort och gott 
Tabell 9.2. Social struktur bland män födda 1865-1874, Göteborg 1915. Källa: Äldrekohorten, GOPP.

\begin{tabular}{llrc} 
HISCLASS & Yrkeskategori & Antal & Andel (\%) \\
\hline 1 & Högre chefer & 1 & 0,7 \\
2 & Högre akademiker & 7 & 4,6 \\
3 & Lägre chefer & 10 & 6,5 \\
4 & Lägre akademiker, kontors- och handelsanställda & 29 & 18,8 \\
5 & Lägre kontors- och handelsanställda & 15 & 9,7 \\
6 & Förmän & 7 & 4,6 \\
7 & Halvkvalificerade arbetare & 30 & 19,5 \\
8 & Jordbrukare, fiskare & 1 & 0,7 \\
9 & Lågkvalificerade arbetare & 19 & 12,3 \\
10 & Lågkvalificerade jordbruksarbetare & 1 & 0,7 \\
11 & Okvalificerade arbetare & 34 & 22,1 \\
12 & Okvalificerade jordbruksarbetare & 0 & - \\
Summa & & 154 & 100,0 \\
\hline
\end{tabular}

grovarbetare. Som varvssmed skulle Oskar ha tillhört gruppen "halvkvalificerade arbetare", som utgjorde en knapp femtedel av kohorten. Bland de halvkvalificerade arbetarna återfanns även bagare, snickare och plåtslagare, samt typografer, den yrkesgrupp som Lars Olsson studerade. En majoritet av kohorten, åtminstone 60 procent, tillhörde arbetarklassen. Då räknar jag in förmän men inte kontors- och handelsanställda med lägre befattningar.

Med tiden föll en del av kohorten ifrån av olika orsaker: vissa dog, andra flyttade från Göteborg, några går inte att spåra i mantalslängderna. Efter 12 år (1927) återstod närmare 75 procent av kohorten, efter 20 år (1935) omkring 60 procent och vid slutåret 1943 omkring 40 procent. Medianåldern var i utgångsläget 45 år och vid slutpunkten 71 år.

Med åren förändrades också kohortens familjesituation. I utgångsläget var de allra flesta (85 procent) gifta, och av de återstående var dryga 10 procent ogifta och några få frånskilda eller änklingar. År 1935, då medianåldern i kohorten var 64 år, hade antalet gifta sjunkit till 82 procent, vilket främst berodde på att fler blivit änklingar. 
Tabell 9.3. Antal och andel kvarvarande män i kohorten samt deras medianålder och civilstånd, Göteborg 1915-1943. Källa: Äldrekohorten, GOPP.

\begin{tabular}{lcccc} 
År & \multicolumn{2}{c}{ Återstod } & Medianålder (år) & Gifta (\%) \\
\hline 1915 & Antal & $\%$ & & 85 \\
1919 & 158 & 100 & 45 & 85 \\
1923 & 157 & 99 & 49 & 82 \\
1927 & 127 & 80 & 53 & 84 \\
1931 & 117 & 74 & 57 & 83 \\
1935 & 112 & 71 & 60 & 81 \\
1939 & 94 & 59 & 64 & 77 \\
1943 & 83 & 53 & 68 & 73 \\
\hline
\end{tabular}

Som visades i kapitel 3 kunde hemmavarande barn bidra väsentligt till hushållets försörjning. Däremot var det inte så vanligt att fruarna förvärvsarbetade, åtminstone inte i sådan omfattning att de deklarerade inkomster av tjänst eller rörelse. Som visas i tabell 9.4 deklarerade mindre än 5 procent av de gifta männens fruar inkomst av tjänst eller rörelse år 1915. Andelen växte dock över tid och utgjorde över 20 procent i slutet av undersökningsperioden. Kanske berodde det på att kvinnorna fick möjlighet att förvärvsarbeta i och med att barnen växte upp, kanske på att behovet av att förvärvsarbeta ökade till följd av att mannens inkomster i vissa fall sjönk med stigande ålder.

Nordiska museets arbetarminnen innehåller påfallande ofta uppgifter om löner och inkomster. Så även i Oskar Hammarströms fall. Han accepterade en plats på en smedja "mot en veckoavlöning av 6 kr" och senare på Keillers mot "löfte om en timpeng av 17 öre". ${ }^{34}$ Efter det stora lönelyftet i samband med återkomsten till Götaverken säger han dock inget om sin fortsatta inkomstutveckling. Diagram 9.1 visar medianinkomsterna, omräknade i 1914 års prisnivå, för män i Oskars generation i allmänhet samt för arbetare. Det framgår att realinkomsterna för de män som gick in i mellankrigstiden som medelålders steg betydligt fram till 1920-talets slut; mellan 1915 och 1927 steg de med närmare 30 procent. Därefter planade de ut fram till slutet av 1930-talet, följt av ett brant fall. Mellan åren 1939 och 1943, 
Tabell 9.4. Andel gifta män i kohorten vars fruar deklarerade inkomst av tjänst eller rörelse, Göteborg 1915-1943. Källa: Äldrekohorten, GOPP.

\begin{tabular}{lrrrrrrrr}
\hline År & 1915 & 1919 & 1923 & 1927 & 1931 & 1935 & 1939 & 1943 \\
\hline Andel (\%) & 4,4 & 8,3 & 11,5 & 11,2 & 12,9 & 18,4 & 17,2 & 23,9 \\
\hline
\end{tabular}

det vill säga då kohortens medlemmar närmade sig 70-årsåldern, föll realinkomsterna med 63 procent. Bland män i arbetaryrken var mönstret likartat, även om uppbromsningen under 1930-talet var mindre framträdande.

I tidigare forskning har samband mellan ålder och inkomst ofta presenterats baserat på tvärsnittsdata, det vill säga inkomstuppgifter för individer i olika åldrar vid en given tidpunkt. Särskilt för arbetaryrken framträder då ofta samband som påminner om ett uppochnedvänt U: efter en inledande positiv inkomstutveckling inträder en fas i yrkeslivet då inkomsterna når ett krön för att därefter falla. I ekonomisk-historikern Ulf Olssons undersökning av verkstadsarbetare i Göteborg på 1920-1940-talet hade vanligtvis män i 40-årsåldern de högsta inkomsterna. ${ }^{35}$ Att longitudinella uppgifter, som de diagram 9.1 bygger på, ger en annan bild kan bero på flera saker. ${ }^{36}$ En orsak kan vara att reallönerna tenderar att stiga med tiden och att det kompenserar för de eventuella försämringar av arbetskapaciteten som följer med stigande ålder. När det gällde verkstadsarbetare över 60 år i Göteborg observerade Olsson dessutom att deras inkomster över tid trendmässigt steg snabbare än genomsnittet för åldersgruppen 20-59, från 81 procent av de yngres inkomster 1920 till 97 procent $1938 .{ }^{37}$ Samtidigt minskade andelen arbetare över 6o. Det kan inte uteslutas att den positiva inkomstutvecklingen för äldre verkstadsarbetare delvis berodde på att personer med låg arbetskapacitet gallrades ut. När vi studerar diagram 9.1 bör vi ha i åtanke att medianinkomsterna endast omfattar de män som faktiskt hade inkomster av tjänst. ${ }^{38}$

Diagram 9.2 visar kohortens medianinkomster i förhållande till medianinkomsten för alla män med deklarerade inkomster av tjänst i GOPP. Här framträder ett mönster som påminner om det som ofta framträder i tvärsnittsdata. Inledningsvis tjänade kohortens typiska medlem mer än en typisk manlig löntagare. Över tid, och med stigan- 
Diagram 9.1. Realinkomst av tjänst för män födda 1865-1874, Göteborg 1915-1943. Anm: Medianinkomster i 1914 års prisnivå. Källa: Äldrekohorten, GOPP.

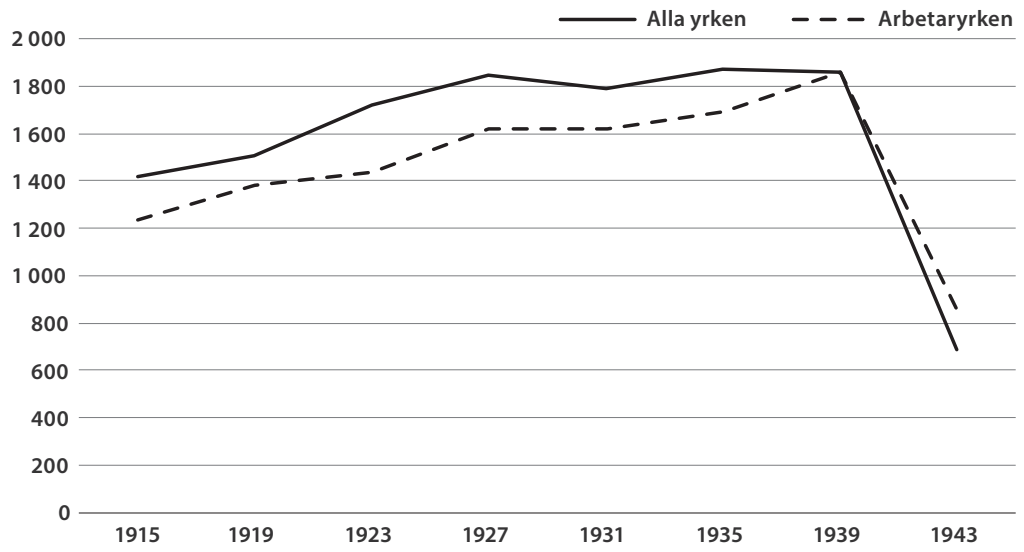

Diagram 9.2. Medianinkomst av tjänst för män födda 1865-1874 i relation till medianinkomsten för alla män, Göteborg 1915-1943. Källa: Äldrekohorten, GOPP.

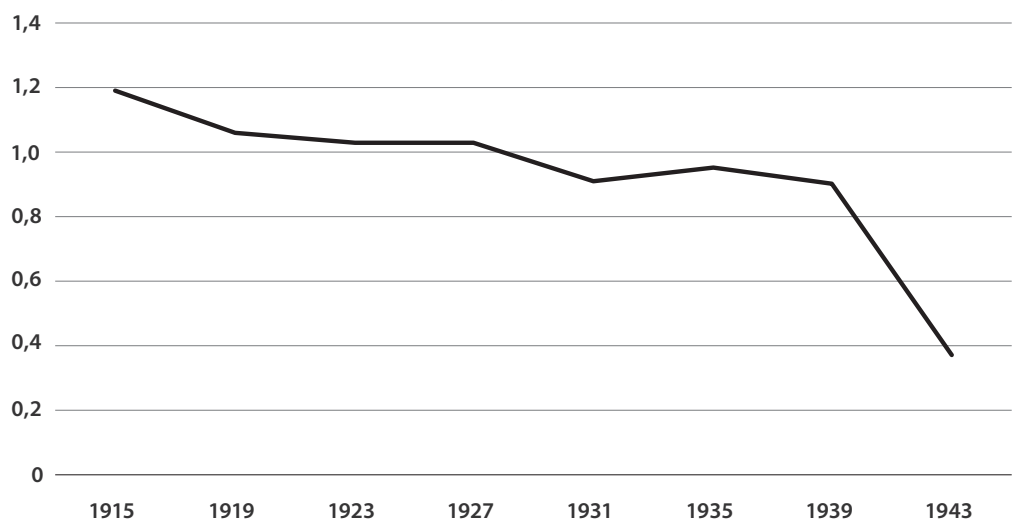

de ålder, minskade medianinkomsten för kohorten i förhållande till GOPP:s manliga population i stort. Minskningen var inledningsvis inte dramatisk. Det var först 1931, då kohortens medlemmar var omkring 60, som inkomsten understeg medianen för arbetsmarknaden i stort, och samma mönster framträder om vi endast ser på män i arbetaryrken. I 70-årsåldern sjönk den relativa inkomsten snabbt. 
Om vi på detta sätt följer en kohort män kan vi alltså samtidigt iaktta att deras realinkomster stiger och deras relativa inkomster sjunker. Det är en svår empirisk utmaning att hålla isär i vilken mån dessa mönster drivs av ålders- respektive periodeffekter. Det är också uppenbart att kohorten blir mindre med tiden, bland annat eftersom fler och fler i kohorten inte alls deklarerar några inkomster av tjänst trots att de fortfarande uppger sig vara yrkesaktiva. Denna grupp torde huvudsakligen bestå av personer som vi idag skulle betrakta som arbetslösa. ${ }^{39}$

Den stigande andelen arbetslösa illustreras i diagram 9.3. Av 45-åringarna 1915 var endast något över 5 procent arbetslösa. Åtta år senare, 1923, i efterdyningarna av den djupa 1920-talskrisen, var andelen 13 procent. I början av 1930-talet närmade sig arbetslösheten i kohorten 20 procent. Därefter låg den på samma nivå till 1939, varefter den steg till närmare 30 procent. Att andelen arbetslösa i kohorten ökade under hela undersökningsperioden kan i grunden ha två orsaker: att inflödet till arbetslöshet ökade och/eller att utflödet från arbetslöshet minskade. Vi kan förmoda att bägge mekanismerna tilltog med kohortens stigande ålder. När deras arbetskapacitet avtog löpte de större risk att förlora jobbet, samtidigt som det blev svårare att få ett nytt jobb eftersom deras kunskaper och färdigheter kanske inte hade hängt med den tekniska utvecklingen. Sannolikt är emellertid den senare mekanismen viktigare för att förklara det vi ser i diagram 9.3. Under mellankrigstiden, i takt med att de fackliga organisationerna blev starkare, kan vi nämligen förmoda att anställningsskyddet stärktes för många grupper på arbetsmarknaden, inte minst de äldre. ${ }^{40}$ Men den teknologiska utvecklingen, liksom rationaliseringsrörelsen i stort, bör ha gjort det svårare för de äldre att hitta nya arbetstillfällen. Här finns emellertid utrymme för vidare forskning.

Diagram 9.4 visar hur andelen yrkesaktiva i kohorten förändrades över tid. Med "yrkesaktiv" menas här att personen uppger ett yrke samt att yrkesuppgiften inte innehåller något tillägg i stil med "före detta" ${ }^{41}$ 
Diagram 9.3. Andel utan inkomst av tjänst, män födda 1865-1874, Göteborg 1915-1943 (procent). Källa: GOPP, Äldrekohorten.

35

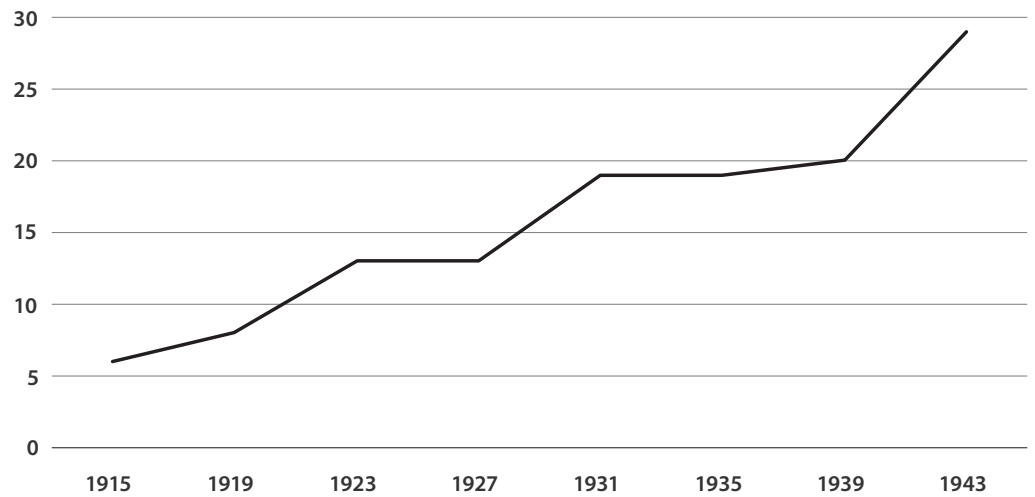

Diagram 9.4. Andel yrkesaktiva efter medianålder, män födda 1865-1874, Göteborg 1915-1943 (procent). Källa: Äldrekohorten, GOPP.

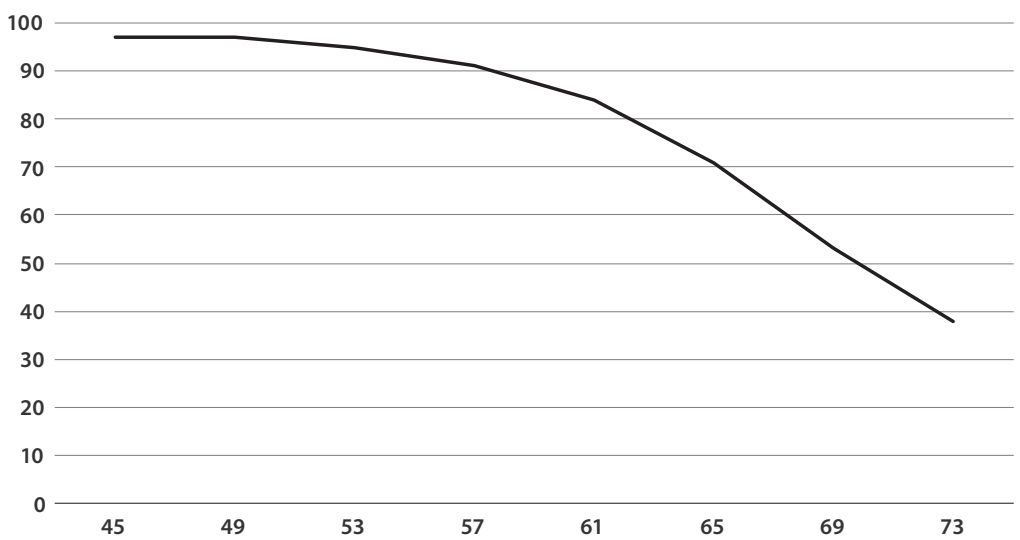

Vid undersökningsperiodens början var nästan alla män i kohorten yrkesaktiva. Andelen minskade sedan gradvis; först långsamt, sedan i snabbare takt. I början av 60-årsåldern var fortfarande närmare 85 procent yrkesaktiva. När kohorten närmade sig 70-årsåldern var andelen 53 procent, och under de följande fyra åren sjönk den yrkesaktiva andelen till 38 procent. Även om utträdet från arbetskraften 
i enskilda fall naturligtvis kan ha varit abrupt måste den kollektiva erfarenheten snarare beskrivas som ett gradvist utträde. Det var inte så att nästan alla var yrkesaktiva fram till 67-årsdagen - den officiella pensionsåldern - och att nästan ingen var yrkesaktiv därefter. Utträdet från arbetsmarknaden inleddes ett bra tag före den officiella pensionsåldern och avslutades ett bra tag efter.

\section{Reträttpositioner för äldre män}

I den historiska forskningen om äldre mäns deltagande i arbetskraften finns en idé om att yrkeslivet kunde förlängas med så kallade reträttpositioner. Istället för att jobba vidare inom samma yrke när den fysiska hälsan sviktade kunde äldre män få befattningar där de fick arbeta i sitt eget tempo. För bagare, ett fysiskt ansträngande yrke med ohälsosam arbetsmiljö, kunde det handla om att söka sig till helt andra näringsgrenar. ${ }^{42}$ Fabriksarbetare kunde jobba som portvakt eller lagerbiträde, det vill säga servicefunktioner utanför den direkta tillverkningen men på samma arbetsplats. Det kan tänkas ha varit särskilt vanligt på arbetsplatser som präglades av ett äldre slags paternalism, enligt vilken arbetsgivaren hade ett socialt ansvar för åldrade trotjänare. Frågan är emellertid hur många sådana reträttpositioner som faktiskt existerade och om denna typ av yrkesväxling var vanlig bland äldre män i mellankrigstidens Göteborg. Det finns inget i varvssmeden Oskars berättelse som antyder att han på äldre dagar trappade ned i en annan yrkesroll.

Den internationella forskningen om reträttpositioner ger en blandad bild. I en studie av amerikanska förhållanden 1870-1930 talar Roger Ransom och Richard Sutch om "pensionering på jobbet" (onthe-job retirement), som de menar var vanligt förekommande. ${ }^{43}$ Detta mönster finns dock inte i en studie av London i skiftet mellan 1920och 1930-tal, det vill säga de första depressionsåren. ${ }^{44}$ Ett problem i forskningen om äldre på arbetsmarknaden är att den ofta utgår från tvärsnittsdata snarare än data som faktiskt följer individers rörelser över tid. Med hjälp av GOPP kan jag studera äldre mäns rörelser på arbetsmarknaden över tid och ta reda på hur vanligt det var att de 
övergick till befattningar som skulle kunna beskrivas som reträttpositioner.

Frågan är emellertid vilka jobb som kan anses vara reträttpositioner. Ett alternativ är att definiera reträttpositioner som jobb inom handel och service, där det kan förmodas att arbetstempot inte styrdes av maskiner på samma sätt som inom tillverkningsindustrin. Yrkesväxlingar i denna riktning var extremt ovanliga i den studerade kohorten. Av de 119 män som inte arbetade inom handel och service 1915 rörde sig endast två in i dessa branscher fram till 1943.

Ett annat alternativ är att helt enkelt definiera reträttpositioner som nedåtgående social rörlighet, det vill säga från yrken med relativt hög social status till yrken med relativt låg status. Tabell 9.4 visar populationens storlek och medianålder samt antal och andelar som upplevde nedåtgående - samt uppåtgående - social rörlighet under en fyraårsperiod. Som framgår av tabellen går det inte att finna tydliga belägg för att nedåtgående social rörlighet blev vanligare med stigande ålder. Ända upp i 6o-årsåldern var uppåtgående rörlighet faktiskt vanligare än nedåtgående rörlighet. Eventuellt blev nedåtgående rörlighet vanligare i 7o-årsåldern men det är vanskligt att dra några långtgående slutsatser med tanke på att kohorten vid det laget endast bestod av 20 män.

Ett tredje alternativ är att definiera reträttpositioner som egenförsörjning eller småföretagsamhet. I USA menar ekonomisk-historikerna Susan Carter och Richard Sutch att det fanns en "urban yrkesstege" (urban occupational ladder) där egenföretagande representerade det sista steget före pensionen. ${ }^{45}$ Deras hypotes går ut på att egenföretagande var förknippat med oberoende och flexibilitet, något som särskilt äldre män attraherades av och strävade efter att uppnå genom sparande. I praktiken kunde emellertid egenföretagandet också vara en nödlösning, ett sätt att sälja sin arbetskraft under rådande lönenivåer, något man tog till då andra dörrar på arbetsmarknaden var stängda.

För att studera övergångar till egenföretagande utgick jag från de män i kohorten som saknade inkomst av rörelse ett givet år (år $t$ ) och undersökte vilka av dem som fyra år senare deklarerade inkomst av rörelse (tabell 9.6). Denna typ av mobilitet var som synes relativt 
Tabell 9.5. Antal och andel män som upplevde social rörlighet under en fyraårsperiod, Göteborg 1915-1943. Anm: Kriterier för att ingå i urvalet år $t$ är att ha en kod för HISCLASS samt finnas kvar i panelen år $t+4$. I den undersökning som ligger till grund för tabellen används en version av HISCLASS med sju klasser. Källa: Äldrekohorten, GOPP.

\begin{tabular}{lcccccc} 
År & Ålder & Antal individer & \multicolumn{5}{c}{$\begin{array}{c}\text { Position fyra år senare } \\
\text { Lägre (\%) }\end{array}$} & Högre & Högre (\%) \\
\hline 1915 & 45 & 118 & 4 & 3 & 10 & 8 \\
1919 & 49 & 95 & 3 & 3 & 3 & 3 \\
1923 & 53 & 96 & 3 & 3 & 8 & 8 \\
1927 & 57 & 85 & 5 & 6 & 5 & 6 \\
1931 & 61 & 65 & 1 & 2 & 4 & 6 \\
1935 & 65 & 41 & 1 & 2 & 0 & 0 \\
1939 & 69 & 20 & 1 & 5 & 0 & 0 \\
\hline
\end{tabular}

Tabell 9.6. Antal och andel män som skaffade sig inkomst av rörelse under en fyraårsperiod, Göteborg 1915-1943. Källa: Äldrekohorten, GOPP.

\begin{tabular}{lcccr} 
År & Antal individer & Ålder & \multicolumn{2}{c}{ Inkomst av tjänst } \\
& & & N & \%,8 \\
\hline 1915 & 103 & 45 & 6 & 4,8 \\
1919 & 83 & 49 & 4 & 2,3 \\
1923 & 86 & 53 & 2 & 5,1 \\
1927 & 78 & 57 & 4 & 7,2 \\
1931 & 69 & 61 & 5 & 7,1 \\
1935 & 42 & 65 & 3 & 4,2 \\
1939 & 24 & 69 & 1 & \\
\hline
\end{tabular}

ovanlig i vårt material. Sambandet mellan ålder och att bli egenföretagare framstår som svagt. Med undantag för i mitten av 1920-talet skaffade sig omkring 5-6 procent av männen i kohorten inkomst av rörelse från ett observationstillfälle till nästa.

Våra beräkningar visar inte på någon tendens att andelen som hade inkomst av rörelse ökade över tid. Snarast var andelen med inkomst av rörelse högst i början av undersökningsperioden. Flödet ut från egenföretagande var alltså större än flödet in. Däremot finns det uppgifter som tyder på att de som hade inkomst av rörelse i 
Diagram 9.5. Andel som lämnade arbetsmarknaden under den kommande fyraårsperioden, alla yrkesaktiva män respektive yrkesaktiva män med inkomst av rörelse, Göteborg 1915-1943 (procent). Källa: Äldrekohorten, GOPP.

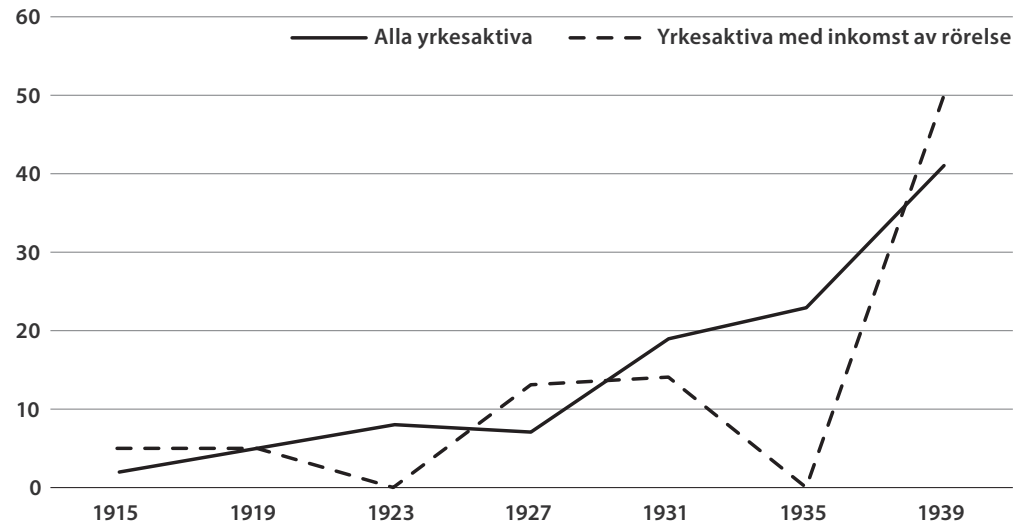

6o-årsåldern i någon mån kunde skjuta upp sitt utträde från arbetskraften. Andelen yrkesaktiva i kohorten sjönk med stigande ålder. Av de 77 män som fortfarande var yrkesaktiva 1931 (då medianåldern var 60 år) hade 20 procent lämnat arbetskraften fyra år senare (se diagram 9.5). Mellan 1935 och 1939 lämnade 23 procent av de kvarvarande männen arbetskraften, men inga av de tio män som hade inkomst av rörelse. Antalet män i högre åldrar som hade inkomst av rörelse är som synes begränsat och skillnaden mellan grupperna kan vara slumpmässig. Resultatet är emellertid intressant i ljuset av debatten om reträttpositioner och äldre män på arbetsmarknaden och bör följas upp i framtida forskning.

\section{Slutsatser}

I det här kapitlet har jag med avstamp i en enskild livsberättelse undersökt äldre mäns erfarenheter av arbetsmarknaden. Jag har med hjälp av data från mantalslängder försökt komplettera och kontextualisera varvssmeden Oskar Hammarströms avskalade skildring av arbetslivets slutfas. Hans berättelse går i linje med en optimistisk uppfattning om äldre mäns villkor under industrisamhällets etable- 


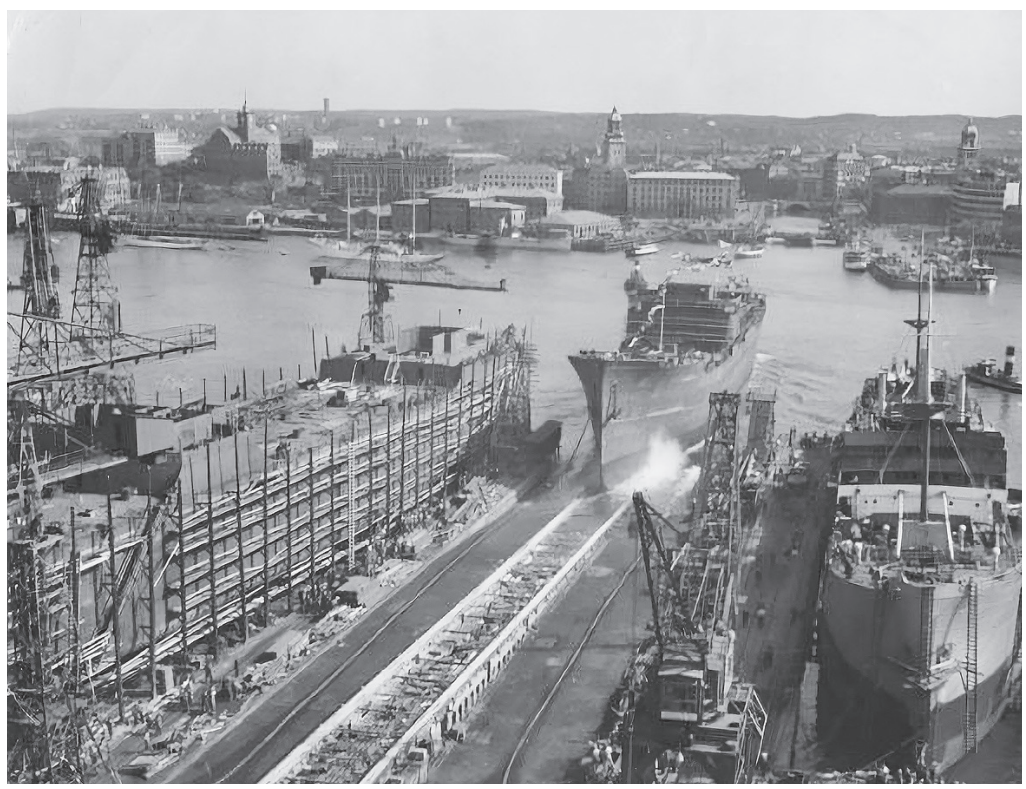

Bild 9.2. Sjösättning år 1947 av M.S. Guyana, ett fartyg tillverkat vid Götaverken. Företaget var då ett av världens största varv och beläget i Lundbyvassen på Hisingen. Foto: okänd fotograf, Göteborgs stadsmuseum.

ringsfas, och vår kvantitativa undersökning visade att exemplet knappast är unikt. De som var medelålders på 1910-talet och som lyckades hålla sig kvar på arbetsmarknaden under de följande årtiondena fick i allmänhet se sin levnadsstandard stiga, om inte jämfört med yngre kollegor så i förhållande till prisutvecklingen. Oskar Hammarström och de flesta i hans generation fortsatte att utöva samma yrke som de hade haft när de trädde in i medelåldern. Att dra sig tillbaka till en reträttposition förekom säkert i enstaka fall men var knappast en typisk erfarenhet. De som hade inkomst från egen rörelse verkar ha skjutit upp sitt slutliga utträde från arbetsmarknaden med några år men inte heller detta var en vanlig företeelse.

Den kvantitativa undersökningen påminde oss om att det också fanns erfarenheter av mörkare slag i Hammarströms generation. Med åren blev allt fler av kohortens medlemmar arbetslösa. Inte sällan måste yrkeslivets slut ha präglats av knappa ekonomiska omständig- 
heter och ett hopplöst sökande efter sysselsättning och alternativa inkomstkällor. Män som hamnade i denna situation var knappast lika benägna, eller förmögna, som Oskar Hammarström att skriva ned sina berättelser.

\section{Noter}

1 Hareven 1994; Högman 1999.

2 Visserligen finns viss flexibilitet i dagens pensionssystem, men på det stora hela är den moderna pensioneringen en relativt abrupt övergång mellan det yrkesaktiva livet och ålderdomen.

3 Under andra halvan av 1930-talet kopplades pensionsnivåerna till regionala prisindex, vilket visade sig särskilt fördelaktigt för personer i Göteborg och andra större städer där det var dyrast att leva. Efter denna reform kom pensionen för en man att motsvara 20 procent av en industriarbetares årsinkomst (Elmér 1960, S 256).

4 Högman 2004.

5 Bäcklund \& Lilja 2014.

6 Lundberg, Svennilson \& Bagge 1933; Svennilson, Lundberg \& Bagge 1935.

7 Andersson \& Eriksson 2017.

8 Andersson, Eriksson \& Lindmark 2010.

9 Bäcklund \& Lilja 2014, s 644.

10 Olsson 1986, s 17.

11 Epstein 1928, s 31.

12 Wallentin 1978, s 42-51.

13 Elmér 1960, s 373.

14 Högman 1999, s 190.

15 Skarin Frykman 1985, s 186.

16 Däremot drabbades många av en förtida död.

17 Olson (1986, s 187) formulerar i sin avslutning hypotesen "att utslagningen av äldre arbetare [...] inträtt tidigare och med större intensitet inom flertalet andra industribranscher än den grafiska”.

18 Som hjälp att organisera sina minnen fick de deltagande arbetarna en frågelista som förutom grundläggande personuppgifter (till exempel födelseår och födelseort) tog upp åtta teman: "barndom och uppväxttid", "barndomshemmet" och dess "omgivning", "första arbetet", "uppväxt och ungdomstid", "äktenskap och familj", "arbetet" samt "andliga och religiösa intressen". För mer utförliga diskussioner om arbetarminnena som källa, se Olsson 1984. Den relativa avsaknaden av upplevelser från livets senare skeden är knappast unik för Nordiska museets arbetarminnen. Gösta Arvastsson (1987, s 76), som intervjuat arbetare som jobbat på några av Göteborgs stora industriarbetsplatser, konstaterar att "de många senare åren på en arbetsplats [kan] bli märkligt befriade från minnen".

19 Rehnberg 1953, s 34-49.

20 Smederna var en stor och betydelsefull yrkesgrupp inom verkstadsindustrin. De hade en stark ställning i förhållande till andra arbetare och till förmän (Isacson \& Magnusson 1983, s 42-46). 
21 Rehnberg 1953, s 49.

22 Rehnberg 1953, s 49.

23 Rehnberg 1953, s 36.

24 Rehnberg 1953, s 38-40.

25 Rehnberg 1953, s 41.

26 Rehnberg 1953, s 35.

27 Svensson 1983, s 146-147.

28 Svensson 1983, s 168.

29 Svensson 1983, s 170-171.

30 Svensson 1983, s 212.

31 Högman 1999, s 44-45.

32 Isacson \& Magnusson 1983, s 42-46.

33 För närmare presentation av GOPP, se kapitel 1 och appendix.

34 Rehnberg 1953, s 42, 44. Allmänt vad gäller verkstadsarbetarnas minnesuppteckningar konstaterade Rehnberg (1953, s 240) att kontroller hade visat att löneuppgifterna var "i stort sett riktiga".

35 Olsson 1970, s 84-85.

36 Becker 1975, s 217-218.

37 Olsson 1970, s 90-91.

38 En sådan tendens bland äldre män i Göteborg, särskilt efter 1935, visas i Karlsson 2015 med hjälp av regressionsanalyser på data från GOPP.

39 Wallentin 1978.

40 Bengtsson 2006.

41 Karlsson 2015.

42 Skarin Frykman 1985, s 186.

43 Ransom \& Sutch 1986.

44 Baines \& Johnson 1999.

45 Carter \& Sutch 1996, s 28-30. 